\title{
Waterbird Foraging Habitat Selection in Balikpapan Bay: Water Depth and Patch Area as Important Factors
}

\author{
Alexander Kurniawan Sariyanto Putera', Dyah Perwitasari-Farajallah ${ }^{2 *}$, Yeni Aryati Mulyani ${ }^{3}$, Stanislav Lhota ${ }^{4}$, Riki \\ Herliansyah $^{5}$, Sodikin 6 \\ ${ }^{1}$ Graduate Program of Animal Biosciences, Department of Biology, Faculty of Mathematics and Natural Sciences, IPB University, \\ Indonesia \\ ${ }^{2}$ Department of Biology, Faculty of Mathematics and Natural Sciences, IPB University, Indonesia \\ ${ }^{3}$ Department of Conservation of Forest and Ecotourism, Faculty of Forestry and Environment, IPB University, Indonesia \\ ${ }^{4}$ Wildlife Management and Conservation Research Group, Department of Animal Science and Food Processing, Faculty of Tropical \\ AgriSciences, Czech University of Life Sciences Prague, Czech Republic \\ ${ }^{5}$ Department of Statistics, Institut Teknologi Kalimantan, Balikpapan, Indonesia \\ ${ }^{6}$ Department of Biology, Faculty of Science and Technology, UIN Sunan Gunung Djati, Bandung, Indonesia
}

\section{ARTICLE INFO}

Article history:

Received July 19, 2021

Received in revised form August 25, 2021

Accepted September 23, 2021

\section{KEYWORDS:}

behavioral ecology,

habitat selection,

patch area,

water depth,

waterbirds

\begin{abstract}
Balikpapan Bay is one of the wetlands providing potential foraging habitat for waterbirds in Indonesia. Potential habitat loss due to oil industry expansion, recent waterbird occurrence, and co-occurrence of two closely related species with similar foraging characteristics led to habitat selection. Habitat selection could be affected by food as an intrinsic factor and extrinsic factor, for example, accessibility to the physical and biological components of the habitat. This study aimed to measure the foraging habitat selection, identify significant habitat quality parameters for the habitat selection and predict the foraging habitat selection model. We used one-zero sampling for collecting foraging habitat selection data, corer sampling for prey data, and collecting the abiotic environment, and Generalized Linear Modelling (GLM) to build the model. We identified four species as the migrant Little Egret (Egretta garzetta), Great Egret (Ardea alba), Purple Heron (Ardea purpurea), and Lesser Adjutant (Leptoptilos javanicus). All species, except Purple Heron, selected foraging habitats. A simple mathematic model of foraging habitat selection was significantly affected by two factors: water depth and patch area. A large patch area may provide primary prey abundance for waterbirds, while a low water depth level may give easy access to the prey.
\end{abstract}

\section{Introduction}

As one of the most extended coastal areas globally, Indonesia has a vital role in providing estuaries from great and small rivers. The estuaries enable mangroves to protect the coastal areas from many threats, such as abrasion, sedimentation, erosion, and intrusion by saltwater (Ilman et al. 2011). Recently, approximately $75 \%$ of the urban area has been located on the coastline, settled by over 100 million people (Badwi et al. 2018). The activities by community living on the coastline included aquacultures like shrimp ponds, industrial areas in some factories, human settlements, and fishing areas. Less promote wetland management and no apparent policy consideration for managing wetlands under the government will decay the natural resources like

\footnotetext{
* Corresponding Author

E-mail Address: witafar@apps.ipb.ac.id
}

wetlands as the waterbird's habitat. One of the wetlands to be concern about is Balikpapan Bay.

Balikpapan Bay is one of Indonesia's most significant oil industries (Tarigan et al. 2017). Most sea transportation is shipped to bring materials and products of industry. The industrial expansion along the coast of Balikpapan Bay has increased since 2017 (Kreb et al. 2020). The expanding oil industry can cause habitat loss for biodiversity along the coast. The mangrove area as a nursery ground for fishes along the coast decreased from 17,620 hectares in 1995 to 16,706 hectares in 2006 (Prayoga et al. 2019). The less the nursery ground area is founded, the less abundant fishes have provided, and the less plenty of fish predator-like waterbirds community are observed.

A waterbird is a group of birds that depend on the wetland. Most of the waterbird activities, spending on wetlands are foraging. The waterbirds such as heron and stork are commonly fed on the mudflat and fish- 
shrimp ponds (Kirby et al. 2008). Some waterbirds from Ardeidae and Ciconiidae can be found in Balikpapan Bay (Putera et al. 2018; Putera 2020). They are purple heron (Ardea purpurea), little egret (Egretta garzetta), great egret (Ardea alba), and lesser adjutant stork(Leptoptilos javanicus). They eat opportunistically in the various mudflat and fish-shrimp ponds: shrimp, crab, and fish (Subaraj and Lok 2009; Nedjah et al. 2010; Katz et al. 2013; Harper and Maccarone 2018).

Interestingly, species of waterbirds such as great egret and purple heron have a similar character during foraging. This character is foraging fishes in solitary. If they are not foraging simultaneously and in the same place, they can compete with each other. On the other hand, if they are foraging, each species will use different resources. This activity is called a competitive exclusion principle (Hardin 1960). This principle can lead to the habitat selection among taxa of waterbirds during foraging in Balikpapan Bay.

Habitat selection showed disproportional use by species of the surrounding environmental factors on the habitat. It involves two factors. The first factor is intrinsic, like the food provided by the habitat (Hutto 1985). The second factor is extrinsic, which is accessible to the physical and biological components of the habitat (Morrison et al. 1992).

Food is necessary to measure the predator's successful fitness (Hutto 1985; Block and Brennan 1993). This success is affected by the predator's foraging response relevant to energy acquired (Pyke 2019). The energy provided by the prey as food, maybe indirectly influence the foraging habitat selection.

On the other hand, accessibility to the physical and biological components also plays an essential role in the foraging habitat selection (Hutto 1985). The physical components are the physical appearance of the habitat, such as water depth and patch area. One of the biological components that matter is prey density.

The physical appearance of the habitat could be referred to as water depth and patch area. In the family Ardeidae, great egret chooses habitat with water depth by $10 \mathrm{~cm}$ to forage (Lantz et al. 2010). Otherwise, lesser adjutant stork uses the foraging habitat with a water depth of approximately $35.56 \mathrm{~cm}$ (Saikia 1995). A patch area also affects the foraging behavior of non-waterbirds (Morrison et al. 2010). However, there was an oil spill incident the Balikpapan Bay in 2018 (MoEF 2018). This incidence will change the physical appearance and reduce the accessibility of coastal areas as the foraging habitat for waterbirds. Water depth, patch area, and oil spills may directly affect the waterbird foraging habitat selection.

Prey density has a vital role in being a good indicator of changes in the coastal wetlands. Their distribution can be related to the water depth. This bioindicator addresses the information of ecological process, which connected to the waterbirds as their food resources (Wingard and Lorenz 2014). For example, little egret has a foraging success rate at higher fish density than low fish density. However, this egret showed a decreasing relative success rate at higher fish density when the egret density was also higher (Vardi et al. 2017). Prey density may influence the foraging habitat selection of waterbirds.

In this study, we measure the foraging habitat selection of the waterbird community from Ardeidae and Ciconiidae on the coastal area of Balikpapan Bay. We examine which factors influence the foraging habitat selection. We also build the model of foraging habitat selection to improve insight into the foraging ecology and habitat management for the waterbird community in Balikpapan Bay.

\section{Materials and Methods}

\subsection{Study Area}

Exploration of the fieldwork was conducted in May 2018 (Rappole et al. 2011) to gain information about the waterbirds' occurrence and their foraging habitat. The exploration area was along coast on the Balikpapan city and Penajam Paser Utara (PPU) regency. We used satellite imagery showing the distribution of oil spills in Balikpapan Bay (Milan Lazecky unpublished data) and a field guidebook to identify the species of waterbirds (MacKinnon et al. 2010). We noted the number of species, their number of individuals, and the type of habitat. Four species were foraging on the mudflat and shrimp pond. They were Purple Heron (Ardea purpurea), Great Egret (Ardea alba), Little Egret (Egretta garzetta), and Lesser Adjutant stork (Leptoptilos javanicus). We saved the sampling locations where they foraged in the GPS receiver, Garmin map 64s.

Thirty-six sampling locations were labeled per location as the species that foraged on the habitat. All sampling locations were located in seven areas based on habitat type. There were two shrimp pond areas and a mudflat area on the Gersik as part of the PPU regency, the northwest Balikpapan Bay. Other areas were one shrimp pond area and one mudflat area located on the Penajam as another part of PPU regency, the 
southwest Balikpapan Bay. The rest were two mudflat areas situated on the Kariangau as part of Balikpapan city, the northeast Balikpapan Bay.

A sampling of the 36 locations was conducted from 13 December 2018 until 27 January 2019. Each location was investigated by following sea tide levels from the lowest tide in the morning to the highest in the afternoon. Information about the status of sea tide was obtained by the DGS Tides software application and corresponding the experienced local fisherman. We used a boat with 8-10 meters in length and 1-2 meters in width to visit the location. There was a maximum of three observers in the boat.

\subsection{Foraging Data Collection}

We used the one-zero sampling method (Altmann 1974) to observe whether species prefer the foraging habitat or not on the location. Each location had a group consisting of 1-5 individuals per species. Five individual at the maximum per species was considered based on observer's ability and provided time. We observed the foraging activity of the species within a 10 seconds interval during two hours each location. The total observation was 72 hours. We observed the species using Nikon Aculon A211 12 x 50 and DSLR Nikon D3100 with $70-300 \mathrm{~mm}$ zoom lens. The foraging category followed the ethogram of the waterbirds (Kushlan 1976, 2007; Saikia 1995; Nota 2003). Success foraging was defined by handling and swallowing the prey for each interval while resting behavior (excluding non-foraging behavior) was defined as foraging activity. Successful foraging was scored as 1 , while a zero value (0) gave foraging activity without success. We measured the frequencies from successful foraging each individual, similar to the number of frequencies from foraging with no success. Both foraging success and no success would be calculated as Manly's standardized selection ratio proportion.

\subsection{Biotic and Abiotic Data Collection}

Biotic data were the prey on the location and categorized into two different groups: fish and crustacean. We used corer sampling by 5 inches in diameter length of corer tube and $1 \mathrm{~mm}$ filter mesh to collect the prey (Howes et al. 2003; Hadi 2016). There were transects with $200 \mathrm{~m}$ in length and $20 \mathrm{~m}$ in width for corer sampling ten times per location. The location of corer sampling was the exact location of the foraging data collection. We conducted the corer sampling after the waterbirds had done their foraging activity.
After corer sampling on the fieldwork, prey samples were dried onto tissue paper for a minute to ensure no water outside the samples. We measured the wet mass on the portable digital scale SF400s and put each sample into the ziplock plastic containing $70 \%$ alcohol for preservation. All preserved samples were stored for the dry mass and ash-free dry mass measurement in the laboratory.

The preserved samples were dried into the ventilated drying oven for 48 hours at $60^{\circ} \mathrm{C}$ to gain the dry mass (Howes et al. 2003). The dried pieces were covered with aluminum foil and stored in the dry box to reach the hot temperature until the warm temperature. The dried samples with warm temperature were measured on the Electronic Balance DJ series HWH model DJ203A to obtain the dry mass of each sample. After dry mass measurement, the dried samples were combusted into a muffle furnace BIOBASE model MF 2.5-12.0 for four hours at $550^{\circ} \mathrm{C}$ to gain the ash-free dry mass. The drying and combustion process was conducted for six months (March-August 2019) in Animal Biosystematics and Ecology Laboratory, Department of Biology, IPB University.

Abiotic data collection was the physical appearance of the habitat. Water depth is measured with a stick of wood marked with a metric ruler with a centimeter (cm) unit of length. Then, the measurement in $\mathrm{cm}$ is converted to the meter $(\mathrm{m})$. A patch area on the field is measured by activating the GPS tracking feature on GPS receiver Garmin map 64s and surrounding the foraging area where the birds are coming forage. Digitations create polygon to create a patch area as a shapefile, based on the fieldwork and the base map. The patch areas are calculated by using area and identify features. We used QGIS 3.8.0-Zanzibar to measure the patch area. For oil spills, the appearance of oil on the water bodies where the water birds forage is scored as 1 , while no oil spill on the water bodies is scored as 0 .

\subsection{Foraging Habitat Selection}

Manly's standardized selection ratio (Manly et al. 2002) is used to measure the habitat selection of waterbird communities during foraging. The habitat selection is calculated from the selection ratio $\left(\mathrm{W}_{i}\right)$ between the proportion of successful foraging for the i sample $\left(\mathrm{O}_{i}\right)$ and the proportion of foraging activity for the i sample $\left(\pi_{i}\right)$. The ratio is informed as below:

$$
\mathrm{B}_{\mathrm{i}}=\mathrm{W}_{i} / \sum_{\mathrm{n}=i}^{\infty} \mathrm{W}_{i}=\left(\mathrm{O}_{i} / \pi_{i}\right) / \sum_{\mathrm{n}=i}^{\infty}\left(\mathrm{O}_{i} / \pi_{i}\right)
$$


Shapiro-Wilk test is used to identify whether both proportions have a normal distribution. A chi-squared test for independence is used to identify the dependency between successful foraging $\left(\mathrm{O}_{i}\right)$ and foraging activity $\left(\pi_{i}\right)$. We used the stats package in R Studio version 1.2.1335 for Shapiro-Wilk and Chi-squared test for independence.

If both proportions come from the normal distribution and have an association, then Confidence Interval (CI) with $95 \%$ can be used. These inferential statistics are used to estimate the proportion of foraging activity as observed proportion. If $\pi \mathrm{i}<\mathrm{CI}$ lower limit, then species choose habitat. There is no habitat preference if $\pi \mathrm{i}>$ CI upper limit. If $\mathrm{CI}$ lower limit $<\pi i<\mathrm{CI}$ upper limit, then habitat preference is neutral. Both non-habitat preference and neutral cannot be used as an indicator of selection (Choi et al. 2017). The analysis of foraging habitat selection is calculated on Microsoft Excel 2013.

\subsection{Factors of the Foraging Habitat Selection}

Factors include prey density, estimated energy, water depth, the presence of oil spills, and patch area. Estimated energy is calculated separately by measuring dry mass (DM) and ash-free dry mass (AFDM). The physical components such as water depth, patch area, and oil spill have been measured directly on the field during abiotic collection.

Prey density $\left(\mathrm{K}_{i}\right)$ is calculated from the number of individual prey for i sample $\left(\mathrm{N}_{i}\right)$ divided by corer area (A) in $\mathrm{m}^{2}$ (previously converted by 10,000 times in $\mathrm{cm}^{2}$ ). The measurement following Hadi (2016) is shown below:

$$
\mathrm{K}_{i}=\left(10,000 \times \mathrm{N}_{i}\right) / \mathrm{A}
$$

The estimated energy of dry mass $\left(E_{i-} D M\right)$ is calculated from the total estimated carbohydrate each DM for the i sample $\left(C_{i D M}=17.55 \mathrm{KJ} / \mathrm{g}\right.$.DM $)$, estimated protein each DM for the i sample $\left(\mathrm{P}_{i \mathrm{DM}}=19.17 \mathrm{KJ} / \mathrm{g}\right.$. $D M)$, and estimated fat each DM for the i sample $\left(\mathrm{L}_{i \mathrm{DM}}\right.$ $=37.54 \mathrm{KJ} / \mathrm{g} \cdot \mathrm{DM})$. This total is divided by the number of types of energy content and times 1,000 to convert from KiloJoule to Joule. The result times each corer area (A) and is divided by 10,000 to convert each corer area (A) from $\mathrm{cm}^{2}$ to $\mathrm{m}^{2}$. The measurement of estimated energy of dry mass is following Brey et al. (2010) as below:

$\mathrm{E}_{i-} \mathrm{DM}=\left(\left(\left(\left(\mathrm{C}_{\mathrm{DDM}}+\mathrm{P}_{i \mathrm{DM}}+\mathrm{L}_{i \mathrm{DM}}\right) / 3\right) \times 1,000\right) \times \mathrm{A}\right) / 10,000$

The estimated energy of ash-free dry mass $\left(E_{i-}\right.$ AFDM) measurement is following Howes et al. (2003) as below:

$$
\mathrm{E}_{i} \_\mathrm{AFDM}=22,000\left(\mathrm{AFDM}_{i} \times 10^{-1} \times \mathrm{A}\right) / 10,000
$$

The estimated energy of AFDM is calculated from AFDM for the $i$ sample $\left(A_{F D M}\right)$ times each corer area (A) divided by the total corer area as $10^{-1}$. The calculation is divided by 10,000 to convert each corer area from $\mathrm{cm}^{2}$ to $\mathrm{m}^{2}$. Then, the result is multiplied by 22,000 as conversion from g.DM.m ${ }^{2}$ (dry mass) to Joule. We calculated all measurements by Microsoft Excel 2013.

\subsection{Identify the Parameters and Build the Best-fitted Model}

A model consisting of the response variable and predictor variable should be identified to identify the parameters of foraging habitat selection. The response variable in this study was the selection ratio (W). The predictor variables in this study were prey density, estimated energy of AFDM, the presence of oil spills, patch area, and water depth.

Multicollinearity test through Variance Inflation Factor (Fox and Weisber 2011) was used to measure the indication of high VIF value. If a VIF value of more than ten is found on the one response variable, this response variable could not be used(Hudjimartsu et al. 2017). The predictor variables should have a VIF value as low as possible $(0<\mathrm{VIF}<3)$ to avoid dependency among predictor variables. If all predictor variables had passed the multicollinearity test, generalized linear modeling (GLM) could be used.

The first step of GLM was identifying the type of data distribution of the response variable by the Kolgomorov-Smirnov test. The next step was analyzed statistically by using GLM and model selection method. Akaike Information Criterion (AIC) was used to select the best model based on the lowest value of AIC. When the best model appeared, the parameters of foraging habitat selection could be identified by t-test. The last step of GLM fitted the best model by Analysis of Deviance with Chisquared-based estimation or Deviance of Goodness of Fit test (Jamilatuzzahro et al. 2018).

All analysis methods were used $\mathrm{R}$ Studio version 1.2.1335 with four packages. There was a car package for multicollinearity test through VIF and Tweedie package for using Tweedie compound Poisson distribution (Foster and Bravington 2013; Bonat and Kokonendji 2017) for the response variable. The last packages were the stats package for the KolgomorovSmirnov test and GLM (Fletcher and Fortin 2018) and the ggplot2 package for visualizing the best and fitted model (Wickham 2016). 


\section{Results}

\subsection{Foraging Habitat Selection in the Waterbirds}

The proportion of foraging success $\left(\mathrm{O}_{i}\right)$ and foraging activity $\left(\pi_{i}\right)$ had a normal distribution. There was no significant difference between foraging success and foraging activity (Table 1).

Twenty-three out of seventy-nine individuals of little egret preferred the foraging habitat in the Balikpapan bay (Figure 1). Twelve individuals

Table 1. Determining the confidence interval of foraging habitat preference

\begin{tabular}{lcc}
\hline \multirow{2}{*}{ The statistical test } & \multicolumn{2}{c}{$\mathrm{W}_{\mathrm{i}}^{\mathrm{a}}(\mathrm{N}=110)$} \\
\cline { 2 - 3 } & $\begin{array}{c}\text { Foraging } \\
\text { success } \\
\text { proportion }\left(\mathrm{O}_{\mathrm{i}}\right)\end{array}$ & $\begin{array}{c}\text { Foraging } \\
\text { activity } \\
\text { proportion }\left(\pi_{i}\right)\end{array}$ \\
\hline Shapiro-Wilk (p-value) & 0.747 & 0.952 \\
& $\left(\mathrm{p}=1.815 \times 10^{-12}\right)\left(\mathrm{p}=5.442 \times 10^{-4}\right)$ \\
Chi-squared test for & $\chi^{2}=0.504 ; \mathrm{df}=109 ; \mathrm{p}$-value $=1$ \\
independence & \multicolumn{2}{c}{0.012} \\
Standard deviation & 0.05 \\
Level of significancy $(\alpha)$ & 0.002 \\
Confidence interval $(\mathrm{CI})$ &
\end{tabular}

aSelection ratio preferred the mudflat, while the other 11 had foraging habitat preference on the shrimp ponds.

The occurrence of the great egret (A.Alba) showing foraging activity could be found on the shrimp pond in Balikpapan Bay (Figure 1). There were 3 of 21 individuals of great egret showing their habitat preferential only to shrimp ponds.

Two of five individuals of lesser adjutant stork ( $L$. javanicus) showed their preference on the mudflat as its foraging habitat in Balikpapan Bay (Figure 1).

Showing no habitat preference to the mudflat and shrimp pond could describe purple heron's less specific foraging habitat (Figure 1).

\subsection{The Best Model with the Factors: Large Patch Area and Shallow Water Depth}

All predictor variables showed no multicollinearity (Table 2) due to low VIF value. Tweedie compound Poisson distribution was matched by the KolgomorovSmirnov test $\left(D=0.563\right.$; -value $=2.2 \times 10^{-16}$; $\mathrm{p}$-value $<0.05)$. It had the Tweedie characteristic: exponential distribution, and the variable response had mass exact at zero.

Model selection showed that models M1 and M2 have the lowest AIC differences (Table 3). Differences ( $\triangle$ AICs) at 0 have substantial support to the model

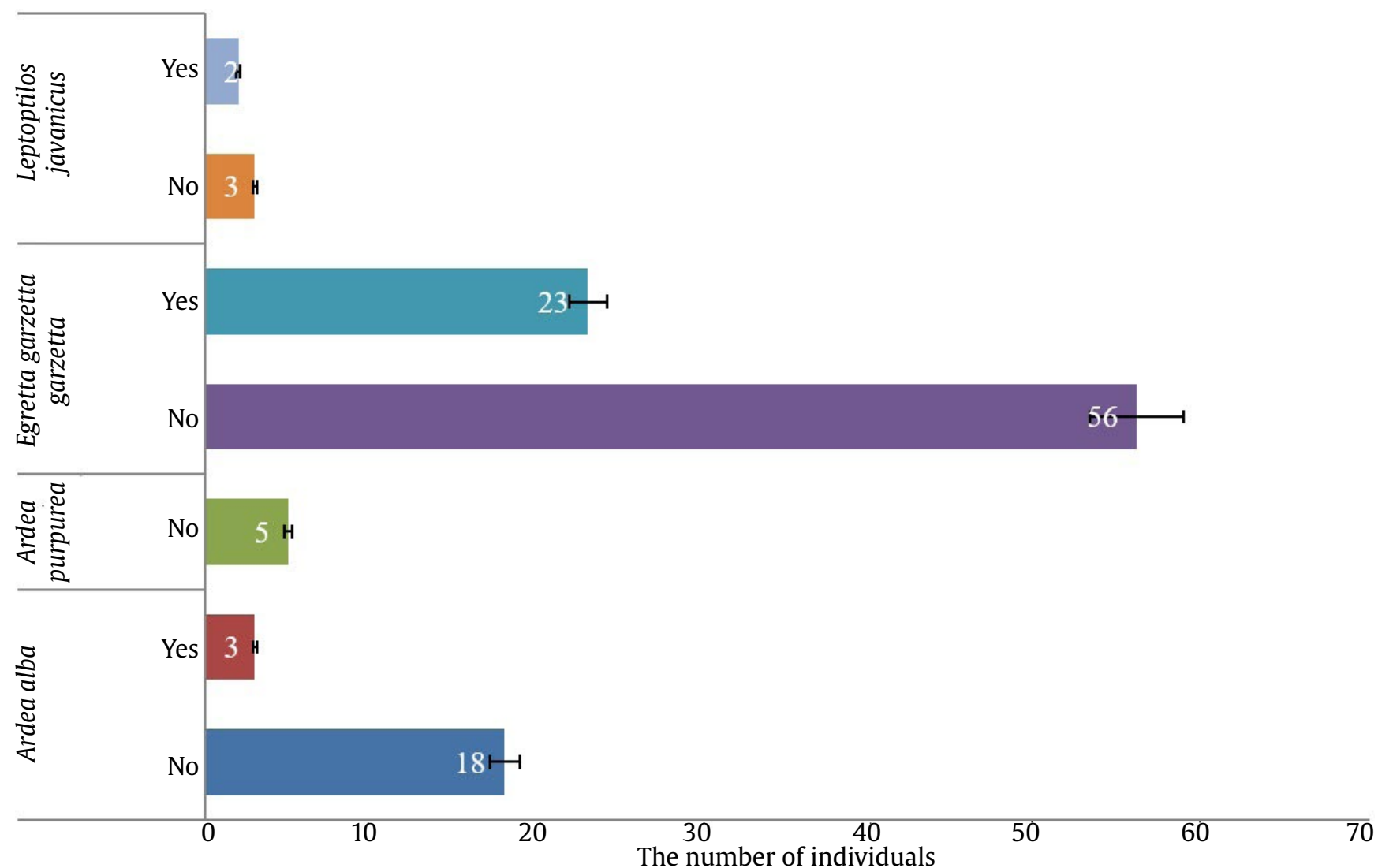

Figure 1. The distribution of foraging habitat selection by waterbirds in Balikpapan Bay 
than AIC differences within 4-7, which explains considerably less support. In the model selection, AIC differences within $>10$ show essentially no support. Furthermore, M1 and M2 are the best models to explain substantial data variation.

Model M2 becomes the best and the fittest model (Table 4), and the model is still consistent, keeping the two factors. These factors are patch area and water depth. GLM has successfully produced the best and fittest model below:

$$
y=-0.361+2.725 \times 10^{-6} x_{1}-4.329 x_{2}+e
$$

With y denoted as foraging habitat selection of waterbirds, denoted as patch area, denoted as water depth, e denoted as error approximately 0.354. A positive mark $(+)$ on the patch area means a large patch area, while a negative mark (-) on the water depth means shallow water depth. Linear predictors are patch area and water depth, and this model has a mean value with a standard error of approximately $0.998 \pm 0.149$ (Figure 2).

\section{Discussion}

\subsection{The Brief Process of Foraging Habitat Selection}

Successful foraging was highly dependent on the foraging activity. Waterbirds were optimizing the foraging activity on their location rather than other locations and the coastal ecosystem in Balikpapan bay. This response could lead to the foraging habitat selection by waterbirds. Each species in the waterbird community could show whether preference for the foraging habitat or not.

Table 2. Multicollinearity among predictor variables

\begin{tabular}{|c|c|c|c|c|c|c|c|}
\hline \multirow[b]{2}{*}{ Collinearity test } & \multicolumn{7}{|c|}{ Predictor variables } \\
\hline & Patch area & Presence of oil spill & E_AFDM fish ${ }^{\mathrm{b}}$ & $\begin{array}{l}\text { E_AFDM } \\
\text { crustacean }^{c}\end{array}$ & $\begin{array}{c}\text { Fish } \\
\text { density }\end{array}$ & $\begin{array}{c}\text { Crustacean } \\
\text { density }\end{array}$ & $\begin{array}{l}\text { Water } \\
\text { depth }\end{array}$ \\
\hline $\mathrm{VIF}^{\mathrm{a}}$ & 2.364 & 2.049 & 1.484 & 1.120 & 1.105 & 1.463 & 1.726 \\
\hline
\end{tabular}

Variance Inflation factor

bEstimated energy from AFDM in fish

cEstimated energy from AFDM in crustaceans

Table 3. Model selection

\begin{tabular}{|c|c|c|c|c|c|}
\hline \multirow[b]{2}{*}{ Model selection } & \multicolumn{5}{|c|}{ Model } \\
\hline & $M 1^{\mathrm{f}}$ & M2g & M3 $^{\text {h }}$ & $\mathrm{M} 4^{\mathrm{i}}$ & $\mathrm{M}^{\mathrm{j}}$ \\
\hline$\overline{\mathrm{AIC}^{\mathrm{d}}}$ & 307.776 & 307.947 & 308.300 & 309.920 & 311.267 \\
\hline$\Delta \mathrm{AIC}^{\mathrm{e}}$ & 0 & 0.172 & 0.525 & 2.145 & 3.491 \\
\hline
\end{tabular}

dAkaike information criterion

eAkaike information criterion differences

fPatch area + presence of oil spill + fish density + crustacean density + water depth

sPatch area + water depth

hPatch area + presence of oil spill + estimated energy from AFDM in fish + estimated energy from AFDM in crustacean + fish density + crustacean density + water depth

iPatch area + presence of oil spill + water depth

jPatch area + presence of oil spill + estimated energy from AFDM in fish + estimated energy from AFDM in crustacean + water depth

Table 4. Fitting the two selected model

\begin{tabular}{|c|c|c|c|c|c|c|c|}
\hline Selected model & \multicolumn{5}{|c|}{ M1 } & \multicolumn{2}{|c|}{ M2 } \\
\hline Predictor variables & Patch area $^{\mathrm{k}}$ & $\begin{array}{l}\text { Presence of oil } \\
\text { spill }\end{array}$ & Fish density & $\begin{array}{c}\text { Crustacean } \\
\text { density }\end{array}$ & $\begin{array}{l}\text { Water } \\
\text { depth }^{k}\end{array}$ & 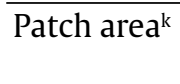 & Water depth \\
\hline$\overline{\text { GLM }}$ & 0.011 & 0.637 & 0.228 & 0.060 & 0.001 & $1.99 \times 10^{-5}$ & $1.68 \times 10^{-4}$ \\
\hline Fit test & $1.555 \times 10^{-7}$ & 0.065 & 0.541 & 0.236 & $1.54 \times 10^{-4}$ & $5.611 \times 10^{-8}$ & $7.805 \times 10^{-5}$ \\
\hline
\end{tabular}

${ }^{\mathrm{k}}$ significant variable $(\mathrm{p}<0.05)$ 


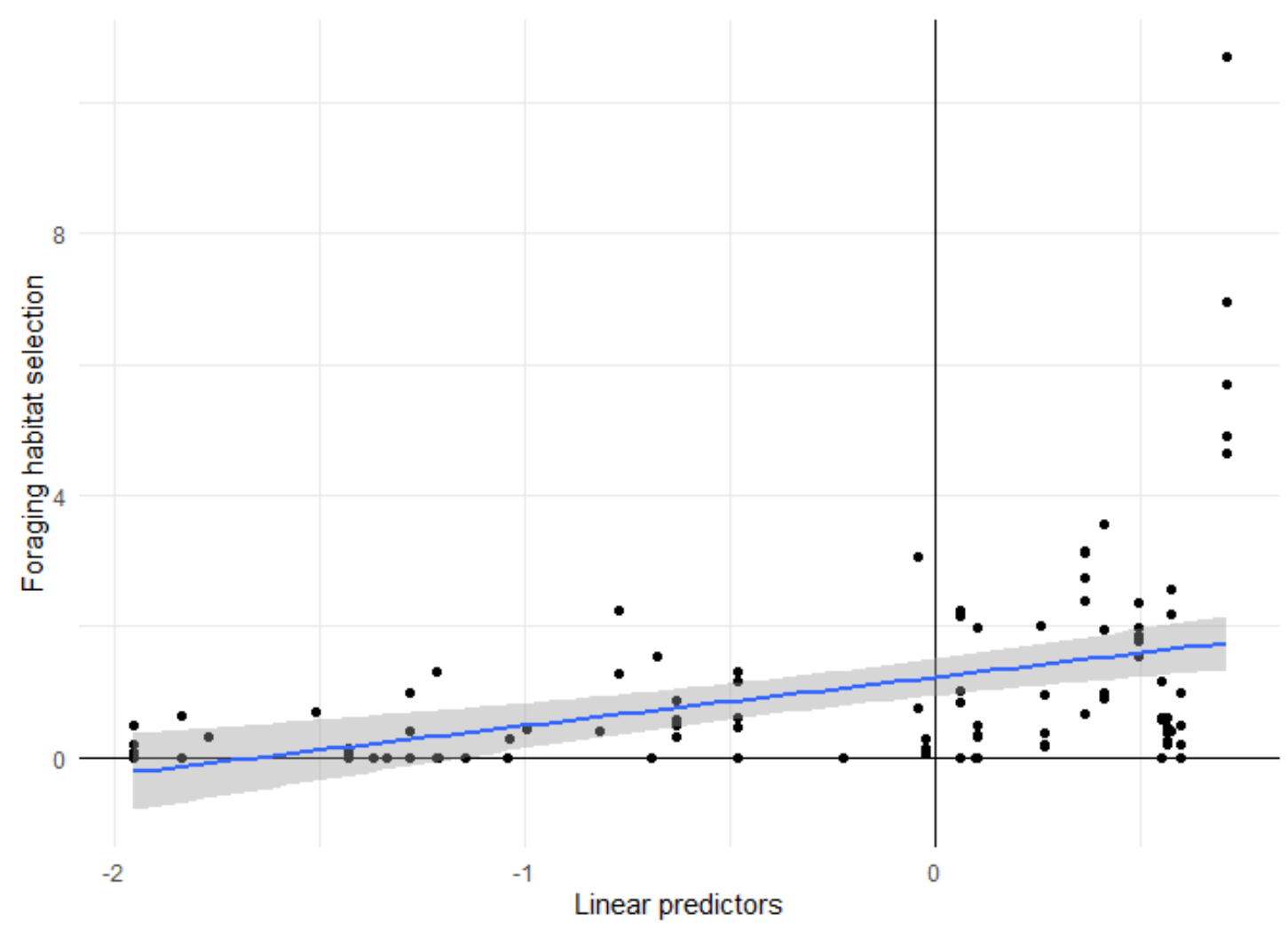

Figure 2. Model-based prediction of waterbird foraging habitat selection in Balikpapan Bay

\subsection{Little Egrets Had a Foraging Habitat Preference}

Three patches were identified as mudflat areas, while one was located on the Gersik, the northwest of the Balikpapan bay (Figure 3). This patch became the only foraging habitat preference on the mudflat by little egret in Balikpapan bay. Interestingly, there was no industrial zone on the Gersik's patch. On the other hand, the rest of the patches were located in the Buluminung Industrial Zone in the PPU regency and the Kariangau Industrial Zone in Balikpapan city.

Little egret might become sensitive due to high industrial activity. The high noise of trucks passing in front of the foraging habitat could disturb little egrets which foraged on the mudflat. When the foraging activity was suddenly stopped due to stress, little egret could run and fly away from the mudflat to the other safe foraging habitat (Ramli and Norazlimi 2017). This response causes no preference by little egret to the foraging habitat nearby industrial zone in Balikpapan bay.

The shrimp ponds in Balikpapan bay provided food resources for more groups of little egret. Four groups showed their preference for the shrimp ponds. 1-5 individuals used this habitat in each group. On the other hand, groups of little egrets that did not show the habitat preference consisted of 4-5 individuals per group.

An individual of little egret could be aggressive to other similar species when this individual has found the foraging habitat like a shrimp pond. The aggressive could be chasing away and barking to the visitor of the foraging habitat. The aggression was lower as decreasing as the number of individuals visiting the habitat. Afterward, this individual was foraging success more frequently to its territorial habitat. This behavior could show a preference to the habitat by the little egret.

The fewer individuals were foraging, the less probability of intraspecific competition happened. This low competition among individuals could optimize each individual to forage different patches. Optimal foraging by an individual of little egret could increase the probability of successful foraging (Vardi et al. 2017). This little egret would protect their foraging habitat from any intruders (Nota 2003). Consequently, this individual of little egret would visit and forage more continuously (Yamada 1994). Furthermore, the individuals of little egret preferred the shrimp pond in Balikpapan Bay. 


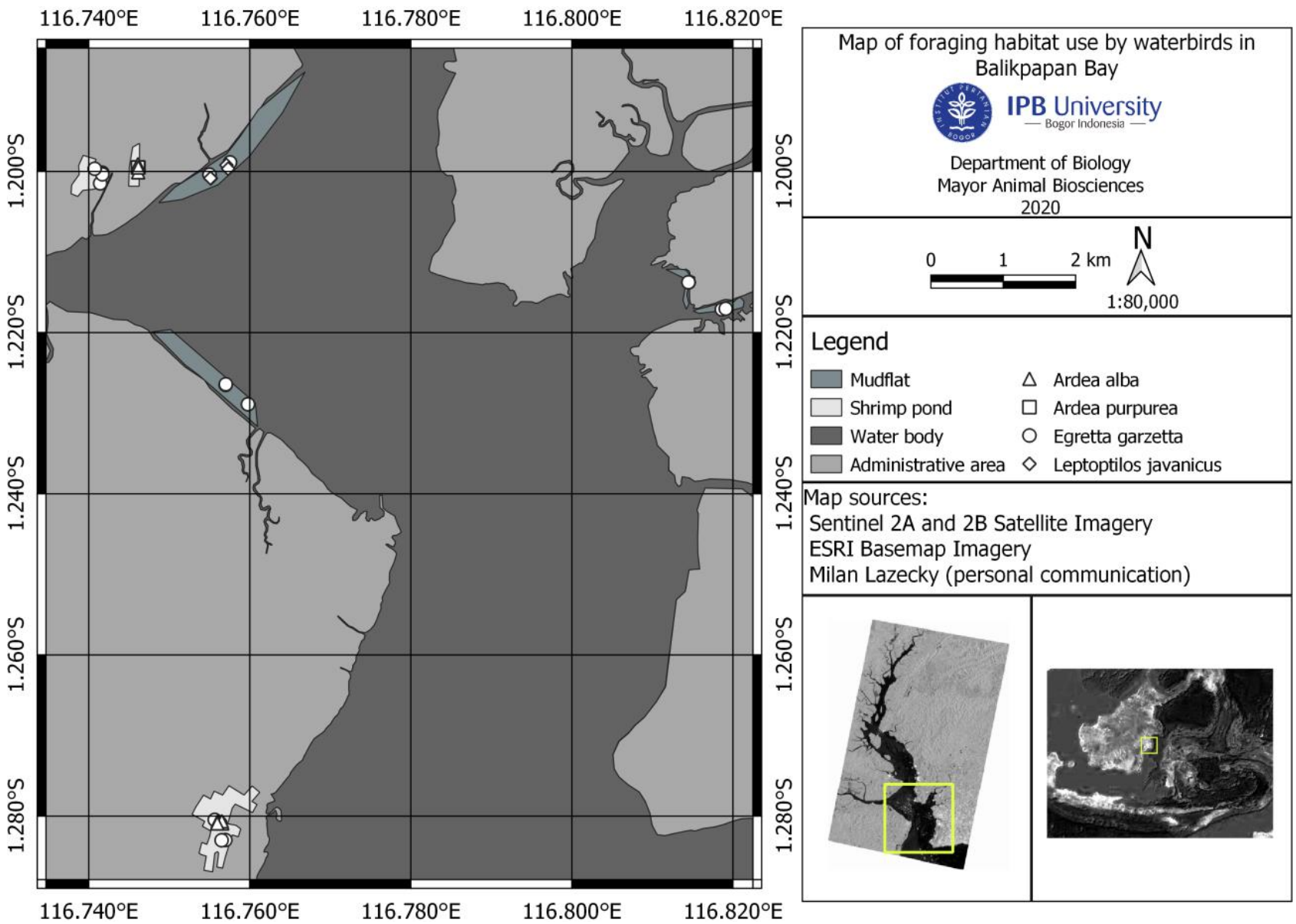

Figure 3. The distribution map of foraging habitat by waterbird in Balikpapan Bay

\subsection{Great Egrets Showing Only their Preference to the Shrimp Pond}

Shrimp ponds in Balikpapan Bay are common aquaculture, especially shrimp (Toulec et al. 2020) instead of fish. The patch area of the shrimp pond was also not more significant than that other patch area like mudflat, except for Great egret.

This species is known as the only egret which foraged crayfish on the pond in the United States. Great egret chose ponds cultivating the crayfish rather than other artificial and natural wetlands habitats in the south of Carolina, United States (Fidorra et al. 2016). The population became larger as increase as the size of ponds with crayfish in the United States over 19 years (Fleury and Sherry 1995). This similar assumption with the observation in Balikpapan Bay could show that this species may prioritize the crustacean as the first prey to avoid the competition among species foraging fish on the similar habitat and similar location at one time. Afterward, the intensively foraging on the habitat to get shrimp in the ponds shows that great egret prefers the specific foraging habitat, especially shrimp pond in Balikpapan Bay.

\subsection{Lesser Adjutant Stork Only Prefers to Forage on the Mudflat}

The stork preferred the mudflat was the local fish trap called sero along the mudflat, and no industrial activity surrounding the mudflat. This condition benefits the lesser adjutant by quickly finding much dying fish after the fish has been trapped for an extended period and no disturbance for the stork foraging on the mudflat.

Local fish traps called sero are commonly found in Balikpapan Bay. These traps are built by using mangrove-made wood fences. These traps direct the fishes to the tip of the trap, following the flows and sea tide level. When the mudflat is an uprising, and the seaside is at the lowest level, the fishes are trapped on the mudflat and become dying (Figure 4). As the most significant proportion foraged by the lesser adjutant stork, most types of prey are fish (Norazlimi 


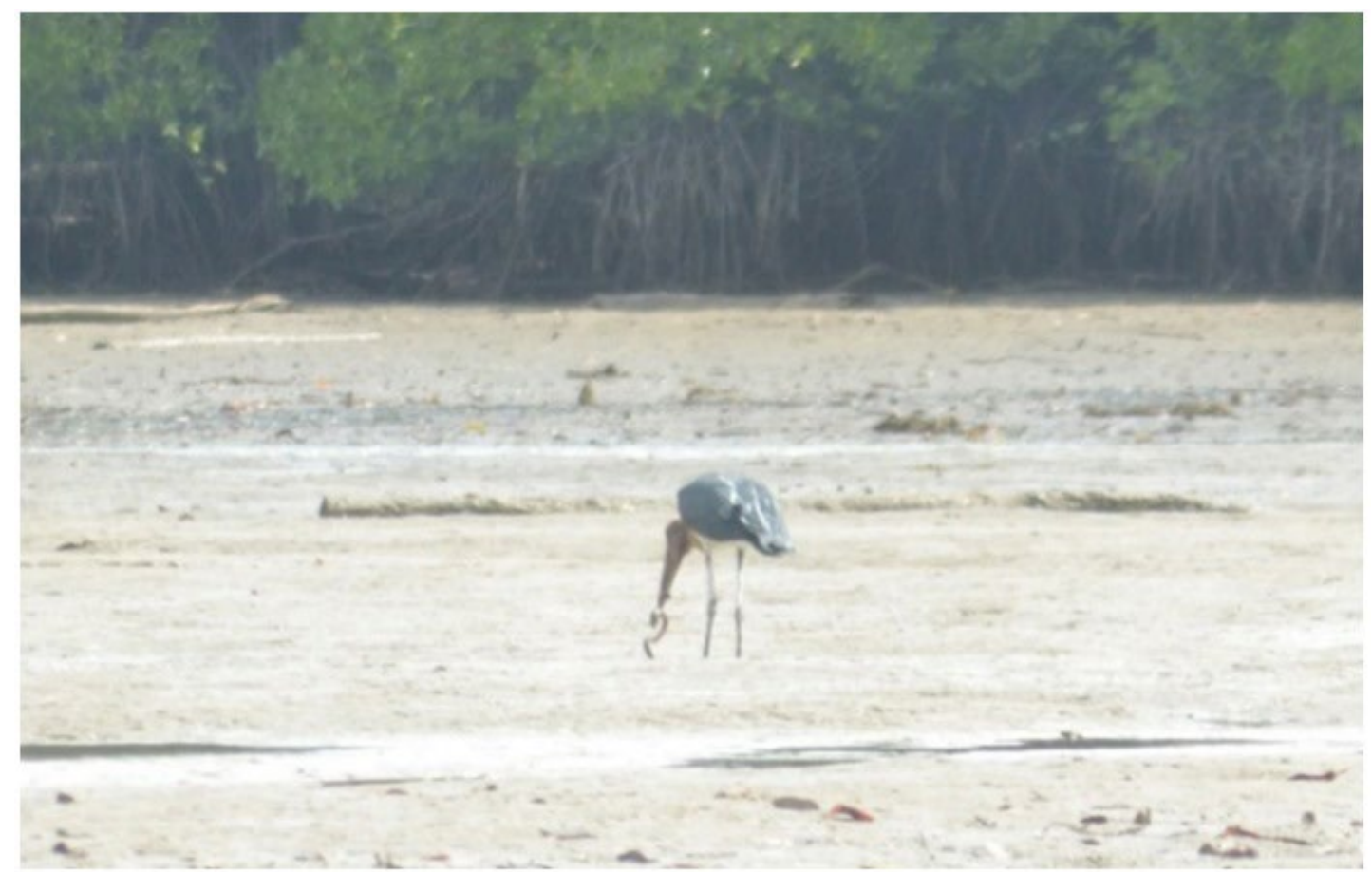

Figure 4. Lesser adjutant stork was catching eel when mudflat was rising in Balikpapan Bay

and Ramli 2015). The lesser adjutant stork takes this opportunity to forage as much as the number of fish dying in the trap.

No industrial zone is also found surrounding the mudflat. This foraging habitat becomes an advantage for the lesser adjutant stork. The stork can reduce the stress at the lowest, and the foraging activity will not be disturbed. Suppose there is any loud voice from industrial activity. In that case, the lesser adjutant stork can show the response by stopping foraging and being aware of the habitat (Ramli and Norazlimi 2017), leading to no preference for foraging habitat.

\subsection{Purple Heron is the only Species Having no Preference for Foraging Habitat}

Purple heron needs the foraging habitat of fish as the primary and most abundant prey on the location. Unfortunately, fish abundance at the shrimp ponds in the PPU regency was less than shrimp abundance at the shrimp pond in a similar regency (Rahmani et al. 2018). In addition, there were a few shrimp ponds in Balikpapan Bay that influenced the prey availability for a purple heron.

Purple herons avoid the habitat occupied by the competitor (Van der Winden et al. 2010) like great egrets. This egret is known as the closely related species and congeneric species to the purple heron. As long as an observation on the fieldwork in Balikpapan Bay, purple heron and great egret were found to coexist foraging on the shrimp pond at one location and time. However, the coexistence was taking a little time. Purple heron decided to leave the shrimp ponds while the great egret continued to forage the shrimp on the ponds. Purple heron's response was confirming no habitat preferential for this heron in Balikpapan Bay.

\subsection{Large Patch Area and Shallow Water Depth as Two Important Factors in the Foraging Habitat Selection Model}

This model has two generally important factors for waterbirds: patch area and water depth. These factors can play a significant role in the foraging habitat selection by waterbirds.

The patch area plays a vital role in the foraging habitat selection by waterbirds. The patch area becomes the most contributing character to the classification of mudflats as the foraging habitat for a group of Ardeidae (Zhang et al. 2018). The larger patch area like mudflat provides the main abundant prey for waterbirds, such as fishes and crustaceans (Erwin 1985).

A larger patch area on the mudflat in Balikpapan bay could inform a high-quality patch for waterbirds. As the optimal foraging theory has suggested for forager's patch choice and use (Pyke et al. 1977), little egret and lesser adjutant stork were optimized during foraging on the mudflat Balikpapan Bay. This decision could maximize the energy gain from the prey and their fitness (Vijayan et al. 2019). These species have 
a higher probability of successful foraging on the selected patch than great egret and purple heron foraging on the poor quality of the patch.

On the other hand, the smaller patch area, for example, shrimp ponds in Balikpapan Bay, provided a few prey, and most of the prey was crustacean such as shrimp and crab. Smaller patch areas might provide less prey availability for waterbirds in Balikpapan Bay. Most of the waterbirds are passive in searching their prey on shrimp ponds. Charnov (1976) had predicted that the patches that vary in quality could lead the forager to stay longer and maximize their foraging activity. Shrimp pond may be the type of patch that does not vary in quality due to aquaculture extension, so no high effort foragers like great egret and purple heron to forage the shrimp and crab as the only prey could be eaten.

Water depth significantly influences the foraging habitat selection. Lantz et al. (2010) observed that a group of Ardeidae selected the foraging habitat based on the shallow water level of about $10 \mathrm{~cm}$. Lesser adjutant stork from Ciconiidae has different responses. This stork foraged on the deeper water level of approximately $35.56 \mathrm{~cm}$ (Saikia 1995).

Water depth can be the threshold to the ability of waterbirds to access the foraging patch depending on their tarsus. The average measurement of tarsus was $6.54 \mathrm{~cm}$ for little egret (Neb et al. 2019), $16.9 \mathrm{~cm}$ for the great egret (Maccarone and Brzorad 2016), and $24.6 \mathrm{~cm}$ for lesser adjutant stork (Saikia 1995). There is an exception to purple heron due to little information about its tarsus measurement.

A little and great egret were getting hard to access the mudflat and shrimp pond in Balikpapan Bay when the water level was higher than their tarsus length. Nevertheless, the lesser adjutant stork was foraging efficiently on the mudflat in Balikpapan Bay, even though the water depth was more profound than its tarsus length. This stork used a specific foraging strategy. This species optimized foraging on the deepwater level rather than shallow water so that the probability of catching larger prey became high. However, after catching the larger prey, then the lesser adjutant stork left the location immediately. The lesser adjutant stork continued the foraging in the shallow water to regain its energy after optimizing foraging on the deeper water level. Furthermore, water depth plays into the factor of ease foraging ability for waterbirds.

The presence of oil spills showed no significant influence on the foraging habitat selection. The typical spill treatment could have been reduced, such as the oil boom and oil skimmer (Redaksi 2018). These tools allowed the separation between oil and water to drop non-soluble oil to the ground, not the water surface (Bahadori 2014). The residual soluble oil was suspended and easily to be observed. However, the residual soluble oil was a little, and most soluble oils adsorbed to the mangrove trees. Waterbirds may be safe for a temporary period, although residual soluble oil on the waterbirds, especially Ardeidae and Ciconiidae, needs to be investigated.

Estimated energy from AFDM in fish and crustaceans does not play an essential role in the foraging habitat selection. The estimated energy from dry mass might not be accurately measured for long-legged waders such as Ardeidae and Ciconiidae instead of shorebirds (Choi et al. 2017). Nevertheless, prey biomass could be measured replacing the estimated energy because prey biomass could estimate diet composition and prey size. Wright et al. (2012) reported that Giant Ibis (Thaumatibis gigantea) is likely to consume greater prey biomass consisting of average-sized eel and crabs rather than averagesized amphibians as prey biomass consumed by White-shouldered Ibis (Pseudibis davisoni). The size of the eel is believed five more times AFDM, while the amphibian size is only 2.5 times AFDM.

Fish and crustacean density is also expected to be the factors. However, it is no sign on the foraging habitat selection. Most collected samples were the small number of individuals and already died. We caught a few living fishes and crustaceans by corer tube. However, the small diameter of 5 inches of corer tube limited the large prey to be caught. The applicable fish or crustacean traps are more practical to get more accurate samples in the future.

\subsection{Model for Sustainability Management of Selected Foraging Habitat by Waterbirds}

Recently, landscape structures have become the best predictors of the ecological response of organisms (Ethier and Fahrig 2011; Jackson and Fahrig 2012). Choosing waterbirds as the indicator is ideal for examining the effects of spatial scales on habitat selection patterns. Waterbirds can survey the landscape, and they have a dynamic annual cycle (Beatty et al. 2014) to move from one location to another due to adaptation to environmental changes. Lesser adjutant stork distribution is affected by shallow water, while herons (e.g., little egret, great egret, and purple heron) have a more comprehensive distribution range following the water level. The finding in this study is supported by (Wang et al. 2020). The suitable habitat for stork in China was primarily focused on high patch concentration, low fragmentation, and minimum impact on surrounding human activities (Wang et al. 2020), which can be 
found on the mudflat in Gersik. On the other hand, herons have suitable habitats in patches, highly fragmented and diverse from ponds to mudflats in China (Wang et al. 2020), resulting from this study. Little egret can be found on all shrimp ponds and mudflats in Balikpapan Bay. Great egret and purple heron can be found only on the shrimp ponds in Gersik and Penajam. The distribution of waterbirds has been created into the model in this study.

The model is built based on the recommendation by McGarigal et al. (2016) about multi-scale habitat selection modeling. Manly's standardize selection ratios as a resource selection function analyzed in a GLM as the conceptual framework has been recommended. Moreover, GLM has been facilitated by AIC as the use of the model selection method based on the likelihood framework. A particular aspect of this framework is to incorporate a hierarchical or multi-level structure to the model with relative ease. This aspect leads to show that different species as a multi-level structure can select habitat at different scales.

Recently, researchers worldwide have conducted many efforts and built models to promote habitat management and waterbirds conservation. Wang et al. (2020) propose their model showing preferred habitats with patch concentrations and robust connectivity for the stork, while preferred habitats with fragmented patches and diverse types for herons. (Hagy et al. 2017) promote their model of the sanctuary area for waterbirds and $342-783 \mathrm{~m}$ as the distance between humans and waterbirds for recreational opportunities to minimize human disturbance. Teng et al. (2021) offer a simple method using the Normalized Difference Water Index (NDWI) as a satellite-based indicator for visualizing the model, which could explain the occurrence of geese at least $42 \%$ caused $75 \%$ of water level changes from 2018 to 2019.

On the local hand, the support of many stakeholders for habitat management and waterbirds conservation can be found in Indonesia. Purify et al. (2019) suggest a map of a habitat suitability model for waterbirds in Lantebung Mangrove Ecotourism Area, Makassar city, to support habitat management in ecotourism areas waterbirds conservation. In this study, we have provided the simple mathematical equation model as the basis of habitat modeling for waterbirds. Great egret and lesser adjutant stork in this model are protected by regulation of the Indonesian government (P.102/MENLHK/SETJEN/KUM.1/6/2018), and the stork is also listed as a vulnerable species, one of the globally threatened species in the IUCN red list. The local community in Balikpapan has raised their awareness to conserve the lesser adjutant stork by reporting the stork to the Nature Conservation Agency in Balikpapan in recent years (Official NET News 2019; Portal Balikpapan 2020).

In a nutshell, there is a foraging habitat selection by waterbirds in Balikpapan Bay. Little egrets prefer to forage in both mudflat and shrimp ponds. Great egrets only show preference to the shrimp pond, while Lesser adjutant storks choose the mudflat foraging habitat. The purple heron decides no preference for either mudflat or shrimp pond. Patch area and water depth influence the waterbird foraging habitat selection. The best and fittest model of waterbird foraging habitat selection is selection ratio (W) as a variable response, while large patch area and shallow water depth become variable predictors.

This model can be used as a basis for wetland management and conservation of waterbirds on their habitat in Balikpapan Bay. There is the following recommendation based on this model:

1. Proposed the mudflat and shrimp pond in Gersik to be sanctuary areas for waterbirds. The owner of shrimp ponds and the local fish trap called sero on the mudflat in Gersik can manage their properties as long as there is no physical harm to the waterbirds and no degradation habitats. Human activity on the mudflat and shrimp pond in Gersik is only allowed to the owners. The implementation can contribute to SDG 15 (Life on Land).

2. The empowerment of the local community is integrated into the proposed waterbird sanctuary areas in Gersik. The owner of shrimp ponds and sero on the mudflat in Gersik can be the keeper of sanctuary areas. The government can collaborate with the keeper to maintain the waterbird sanctuary areas in Gersik. The implementation can contribute to SDG 12 (Responsible Consumption and Production).

3. To ensure that cash flow for budgeting the waterbird sanctuary area is sustainable, the keeper guide avitourism. A workshop about ecotourism and agritourism is needed to transfer knowledge for the keeper. The implementation can contribute to SDG 8 (Decent Work and Economic Growth).

4. We can survey other potential mudflat and shrimp ponds (if any) on the whole coast of Balikpapan Bay in the future. The important thing during the subsequent fieldwork measures patch area and water depth by following similar fieldwork in this study. The foraging habitat selection can be defined for each potential habitat. The implementation can contribute to SDG 14 (Life below Water).

5. Surveying the potential habitats can inform the government to regulate the policy to reach sustainable development goals (SDGs). 


\section{Acknowledgements}

We would like to thank for Darman and Hery Seputro who helped the fieldwork, and Usti nad Labem Zoo with Český svaz ochránců prírody (ČSOP) as the financial support to this research.

\section{References}

Altmann J. 1974. Observational study of behavior: sampling methods. Behaviour 49227-267.

Badwi N et al. 2018. Abrasion hazard mitigation efforts on the coast Maros regency of South Sulawesi, Indonesia. In: Proceedings of the International Conference on Advanced Multidisciplinary Research (ICAMR2018), Makassar, Vol 227. Dordrecht: Atlantis Press. pp. 430-433.

Bahadori A. 2014. Pollution Control in Oil, Gas, and Chemical Plants. Cham: Springer International.

Beatty WS et al. 2014. Landscape effects on mallard habitat selection at multiple spatial scales during the nonbreeding period. Landsc Ecol 29:989-1000.

Block WM, Brennan LA. 1993. The habitat concept in ornithology: theory and applications. Curr Ornithol $11: 35-91$

Bonat WH, Kokonendji CC. 2017. Flexible tweedie regression models for continuous data. JStat Comp Simul 87:21382152.

Brey T et al. 2010. Body composition in aquatic organisms-a global data bank of relationships between mass, elemental composition, and energy content. J Sea Res 64:334-340.

Charnov EL. 1976. Optimal foraging, the marginal value theorem. Am Nat 110:141-151.

Choi CY et al. 2017. How migratory shorebirds selectively exploit prey at a staging site dominated by a single prey species. Auk 134:76-91.

Erwin RM. 1985. Foraging decisions, patch use, and seasonality in egrets (Aves: Ciconiiformes). Ecology 66:837-844.

Ethier K, Fahrig L. 2011. Positive effects of forest fragmentation, independent of forest amount, on bat abundance in eastern Ontario, Canada. Landsc Ecol 26:865-876.

Fidorra JC et al. 2016. Selection of human-influenced and natural wetlands by great egrets at multiple scales in the southeastern USA. Condor 118:46-56.

Fletcher R, Fortin MJ. 2018. Spatial Ecology and Conservation Modeling: Applications with $R$. Cham: Springer Publishing.

Fleury BE, Sherry TW. 1995. Long-term population trends of colonial wading birds in the southern United States: the impact of crayfish aquaculture on Louisiana populations. Auk 112:613-632.

Foster SD, Bravington MV. 2013. A Poisson-Gamma model for analysis of ecological non-negative continuous data. Environ Ecol Stat 20:533-552.

Fox J, Weisberg S. 2011. An R Companion to Applied Regression. Second ed. Thousand Oaks: Sage.

Hadi NK. 2016. Ekologi makan burung pantai dan kaitannya dengan kondisi lingkungan lahan basah Wonorejo, Surabaya [Thesis]. Bogorm, Indonesia: IPB University.

Hagy HM et al. 2017. Evaluating tradeoffs between sanctuary for migrating waterbirds and recreational opportunities in a restored wetland complex. Hydrobiologia. 804:103118.

Hardin G. 1960. The competitive exclusion principle. Science 3409:1292-1297.

Harper AC, Maccarone AD. 2018. Comparisons of foraging behaviour and energetic by great egret (Ardea alba) and snowy egret (Egretta thula) across three microhabitats. Transactions of the Kans Academy of Science 121:179185.
Howes J et al. 2003. Panduan Studi Burung Pantai. Bogor: Wetlands International Indonesia.

Hudjimartsu SA et al. 2017. Prediction of the spread of Acacia nilotica invasive species using generalized linear models. J Manaj Hutan Tropika 23:150-157.

Hutto RL. 1985. Habitat selection by non-breeding, migratory land birds. In: Cody ML(Eds.). Habitat Selection in Birds. New York: Academic Press. pp. 455-476.

Ilman $\mathrm{M}$ et al. 2011. State of the Art Information on Mangrove Ecosystems in Indonesia. Bogor: Wetlands International-Indonesia Programme.

Jackson HB, Fahrig L. 2012. What size is a biologically relevant landscape?. Landsc Ecol 27:929-941.

Jamilatuzzahro et al. 2018. Aplikasi Generalized Linear Model pada $R$. Yogyakarta: Innosain.

Katz MW et al. 2013. Optimal foraging of little egrets and their prey in a foraging game in a patchy environment. Am Nat 3:381-395.

Kirby JS et al. 2008. Key conservation issues for migratory land and waterbird species on the world's major flyways. Bird Conserv Int 18:49-73.

Kreb D et al. 2020. Long-term population and distribution dynamics of an endangered Irrawaddy dolphin population in Balikpapan Bay, Indonesia in response to coastal development. Front Mar Sci 7:533197.

Kushlan JA. 2007. Sympatric foraging of little egrets and snowy egrets in Barbados, West Indies. Waterbirds 30:609-612.

Kushlan JA. 1976. Feeding behavior of North American herons. Auk 93:86-94

Lantz SM et al. 2010. The effects of water depth and submerged aquatic vegetation on the selection of foraging habitat and foraging success of wading birds. Condor 3:460469.

Maccarone AD, Brzorad JN. 2016. Intraspecific and intersexual variation in three species of wading birds using morphometric measurements. Waterbirds 39:205-208.

MacKinnon J et al. 2010. Burung-burung di Sumatera, Jawa, Bali dan Kalimantan. Bogor: LIPI-Burung Indonesia.

Manly BFJ et al. 2002. Resource Selection by Animals: Statistical Design and Analysis for Field Studies. Second ed. Dordrecht: Kluwer Academic Press.

McGarigal Ket al. 2016. Multi-scale habitat selection modeling: a review and outlook. Landsc Ecol 31:1161-1175.

MoEF 2018. Laporan Tim Penanganan Kejadian Tumpahan Minyak (Oil Spill) di Perairan Teluk Balikpapan Kota Balikpapan dan Kabupaten Penajam Pasir Utara, Provinsi Kalimantan Timur. Jakarta: Ministry of Environment and Forestry.

Morrison EB et al. 2010. Patch size effects on avian foraging behavior: implications for the tropical forest restoration design. J Appl Ecol 47:130-138.

Morrison MLet al. 1992. Wildlife-habitat Relationships: Concepts and Applications. Madison: University of Wisconsin Press.

Neb A et al. 2019. Body condition of little egret Egretta garzetta nestlings in relation to hatching order in a southern Tunisian breeding colony. Ostrich 90:91-96.

Nedjah R et al. 2010. Breeding ecology of the purple heron Ardea purpurea in Numidia, north-eastern Algeria. Ostrich 3:189-196.

Norazlimi NA, Ramli R. 2015. The relationships between morphological characteristics and foraging behaviour in four selected species of shorebirds and water birds utilizing tropical mudflats. Sci World J 2015:1-7.

Nota Y. 2003. Effects of body size and sex on foraging territoriality of the little egret (Egretta garzetta) in Japan. Auk 120:791-798.

Official NET News 2019. Available at: https://www.youtube. com/watch?v=MFWcC301T7c. [Date accessed: 21 May 2021] 
Portal Balikpapan. 2020. Available at: https://web.facebook. com/portalbalikpapan/posts/seekor-burung-bangaotong-tong-ditemukan-di-kawasan-telindung-dekatpemakaman-he/3091914474161076/?_rdc=1\&_rdr. [Date accessed: 21 May 2021]

Prayoga AP et al. 2019. Status and Strategy to Protect Mangrove Ecosystems in Indonesia, Case study: Mangrove Ecosystem in Balikpapan Bay East Kalimantan. Bogor: Forest Watch Indonesia.

Purify A et al. 2019. Water bird habitat suitability analysis in an urban coastal wetland (case study: Lantebung mangrove ecotourism area). In: Proceedings of the 2nd International Symposium on Marine Science and Fisheries (ISMF2), Makassar, Vol 370. Bristol: IOP Conf Ser: Earth Environ Sci. pp. 012042.

Putera AKS. 2020. Pemilihan Habitat dan Strategi mencari Mangsa pada Kelompok Burung air di Teluk Balikpapan [Thesis]. Bogor, Indonesia: IPB University.

Putera AKS et al. 2018. Diversity, composition, and abundance distribution of birds in Kariangau Industrial Zone, Balikpapan City, East Borneo. Biosaintifika J Biol and Biol Educ 3:605-612.

Pyke GH. 2019. Optimal Foraging Theory: An Introduction. In: Choe JC (Eds.). Encyclopedia of Animal Behavior, second ed. Amsterdam: Elsevier Academic Press. pp. 111-117.

Pyke GH et al. 1977. Optimal foraging: a selective review of theory and tests. Q Rev Biol 52:137-154.

Rappole JH et al. 2011. Ornithological exploration in the southeastern Sub-Himalayan Region of Myanmar. Ornithol Monogr 70:10-29.

Rahmani MR et al. 2018. Peran dinas perikanan dalam pengelolaan peningkatan produktivitas perikanan pembudidaya tambak di kecamatan Babulu kabupaten Penajam Paser Utara. IIP 6:1087-1098.

Ramli R, Norazlimi NA. 2017. The effects of disturbance on the abundance and foraging behaviour of shorebirds and waterbirds in the tropical mudflat areas. Sains Malay 46:365-372.

Redaksi 2018. Available at: https://www.portonews.com/2018/ oil-and-chemical-spill/penanganan-tumpahanminyak-di-teluk-balikpapan-cukup-efektif/. [Date accessed: 3 May 2021]

Saikia PS. 1995. Ecology of Adjutant Storks with special reference to Leptoptilos javanicus (Horsfield) in the Brahmaputra Valley, Assam [Dissertation]. Guwahati: Gauhati University.
Subaraj R, Lok AFSL. 2009. Status of the lesser adjutant stork (Leptoptilos javanicus) in Singapore. Nat Sing 2:107-113. Tarigan AKM et al. 2017. Balikpapan: urban planning and development in anticipation of the post-oil industry era. Cities 60:246-259.

Teng J et al. 2021. Assessing habitat suitability for wintering geese by using Normalized Difference Water Index (NDWI) in a large floodplain wetland, China. Ecol Indicators 122, 107260.

Toulec T et al. 2020. Shrimp farms, fire, or palm oil? Changing causes of proboscis monkey habitat loss. Glob Ecol Conserv 21:e00863.

Vardi R et al. 2017. How does the presence of a conspecific individual change the behavioral game that a predator plays with its prey?. Oecologia 184:597-607.

Van derWinden Jet al. 2010. Slaapplaatsen en foerageergebieden van Purperreigers in het Groene Hart in de nazomer. Limosa 83:109-118.

Vijayan S et al. 2019. Time to revisit? a predator's previous successes and failures in prey capture determine its return time to patches. Oecologia 190:387-397.

Wang C et al. 2020. Diverse usage of waterbird habitats and spatial management in Yancheng coastal wetlands. Ecol Indic 117:106583.

Wickham H. 2016. ggplot2: Elegant Graphics for Data Analysis, second ed. Cham: Springer International.

Wingard GL, Lorenz JJ. 2014. Integrated conceptual ecological model and habitat indices for the southwest Florida coastal wetlands. Ecol Indic 44:92-107.

Wright HL et al. 2012. Foraging ecology of sympatric white-shoulder ibis Pseudibis davisoni and giant ibis thaumatibis gigantean in northern Cambodia. Forktail 28:93-100.

Yamada K. 1994. Feeding behaviour and territoriality according to the prey types and habitat in the little egret Egretta garzetta. Ipn J Ornithol 42:61-75.

Zhang M et al. 2018. Habitat features rather than competition explain the distribution and co-occurrence of Ardeidae in a highly urbanized landscape. Waterbirds. 41:46-55. 